Indian Journal of Science and Technology

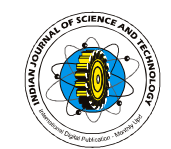

\title{
Silver nanoparticle loaded on activated carbon as efficient adsorbent for removal of methyl orange
}

\author{
H Karimi", S Mousavi and B Sadeghian \\ Chemical Engineering Department, Gachsaran Branch, Islamic Azad University, Gachsaran, Iran \\ hakar@mail.yu.ac.ir*
}

\begin{abstract}
Silver nanoparticle loaded on activated carbon were synthesized and used for the removal of methyl orange (MO) from aqueous solutions. The influence of variables such as initial solution $\mathrm{pH}$, amount of adsorbent, initial $\mathrm{MO}$ concentration and adsorption time on its removal percentage was studied. The equilibrium adsorption isotherms have been analyzed by Langmuir, Freundlich and Tempkin models. It was found that Langmuir model has the highest correlation coefficients. The fitting experimental data to different conventional kinetic models such as pseudo-first and pseudosecond order, Elovich and intraparticle diffusion kinetic models show that adsorption follow the second-order equation in addition to intraparticle diffusion as the rate-limiting factor.
\end{abstract}

Keywords: Silver nanoparticle, Activated carbon, (Ag-NP-AC), Methyl orange (MO), Adsorption.

Introduction
Due to high consumption of dyes in various processes and industries (food, paper, carpets, rubbers, plastics, cosmetics, and textile) the discharge of colored wastewater from industries causes many significant environmental problems (El Qada et al., 2008). The presence of coloring material in water system reduces penetration of light, thereby affecting photosynthesis in aquatic plankton. Dyes are also a major component of laboratory wastes which are then led into the soil and water-bodies (Ofomaja \& Bioresour, 2008; Chen et al., 2011) posing ecological risks and being toxic to aquatic life when discharged directly into receiving waters. They may be mutagenic and carcinogenic and can cause severe health hazard to humans, such as dysfunction of kidney, reproductive system, liver, brain and central nervous system (Kadirvelu et al., 2003; Zhuannian et al., 2009; Jia, 2009 \& Barhon et al., 2009). Among various dye treatment procedure such as physical, chemical and biological decolorization processes (Kadirvelu et al., 2003; El Qada et al., 2008; Ofomaja \& Bioresour, 2008 \& Chen et al., 2011). The adsorption technique (typical physical process) is widely used to remove pollutants that are not easily biodegradable from waters. Among them, adsorption offers the simplest and cheapest method for treating the wastewater before discharge into water reservoir (Chen et al., 2011). Increasing environmental pollution caused by toxic hazardous nature is a matter of great concern. MO (a water-soluble azo dye) (Fig. 1), is a well-known carcinogenic organic substance which is widely used in textile, printing, paper manufacturing, pharmaceutical and food industries but also in research laboratories as an acid base indicator due to its ability to function as weak acid (Kucukosmanoglu et al., 2006).

Microbial succession and intestinal enzyme activities in developing rats have also been studied for MO (Chang

Fig. 1. MO structure change by $\mathrm{pH}$.
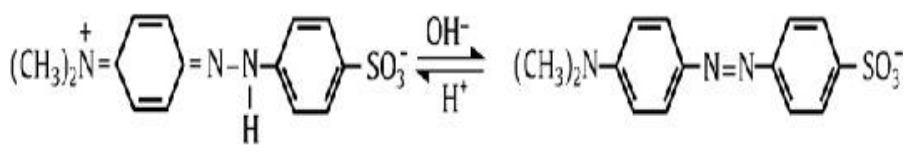

et al., 1994) and this dye was found to increase nitro and azo reductase activities significantly, with the appearance of anaerobes in the large intestine. Always, this dye enter to the body through ingestion, metabolizes into aromatic amines by intestinal microorganisms. Reductive enzymes in the liver can also catalyze the reductive cleavage of the azo linkage to produce aromatic amines, and can even lead to intestinal cancer (Chung KT et al., 1992 \& Chung, 1983). MO regard as allergy materials after contacting by skin, causes shin eczema and even be poisonous if swallowed.

However, metallic nanoparticles tend to either react with surrounding media or agglomerate to result in significant loss of reactivity (Chen et al., 2011). Out of economic consideration, it is not used to treat a large quantity of effluents by a great scale of adsorbent such as activated carbon. However, the adsorption capacities of the above adsorbents are not very high; some even less than $50 \mathrm{mg} \mathrm{g}^{-1}$. To improve the efficiency of the adsorption processes, it is necessary to develop high adsorption capacity and easily available adsorbents.

The objective of the present work is to investigate the potential feasibility of silver nanoparticle loaded on activated carbon (Ag-NP-AC) for the adsorption of MO. The kinetic data and equilibrium data were analyzed to understand the adsorption mechanism by applying different models for the experimental data.

\section{Experimental}

Instruments and reagents

Stock solution was prepared by dissolving a required amount of MO (E. Merck, Darmstadt, Germany) in double distilled water. The test solutions were prepared by diluting stock solution to the desired concentrations (determined at $464 \mathrm{~nm}$ ). The $\mathrm{pH}$ measurements were done using $\mathrm{pH} / \mathrm{lon}$ meter model-686 and adsorption studies were carried out using Jusco UV-Visible spectrophotometer model V-570. All chemicals including $\mathrm{NaOH}, \mathrm{HCl}, \mathrm{KCl}$, activated carbon (AC) were purchased from E. Merck, Darmstadt (Germany).

Measurements of dye uptake

Concentrations of $\mathrm{MO}$ in solution were determined using a calibration curve within the investigated
Research article

CIndian Society for Education and Environment (iSee)
"Methods of analysing missing values in a regression model" http://www.indjst.org
Ogoke U. P. \& Nduka E. C. Indian J.Sci.Technol. 
concentration range. The dye adsorption capacities of adsorbents were determined at certain time intervals (1$21 \mathrm{~min}$ ) for Ag-NP-AC and the equilibrium was established after $15 \mathrm{~min}$. The effect of $\mathrm{pH}$ on adsorption was studied by adjusting $\mathrm{MO}$ solutions $\left(10 \mathrm{mg} \mathrm{L}^{-1}\right)$ to different $\mathrm{pH}$ values (2.0-9.0) and agitating them with 0.02 $\mathrm{g}$ of Ag-NP-AC for $15 \mathrm{~min}$, while the initial dye solution $\mathrm{pH}_{\mathrm{i}}$ were adjusted by addition of $\mathrm{HCl}$ or $\mathrm{NaOH}$. Dye adsorption experiments were accomplished to obtain isotherms at various $\mathrm{MO}$ concentrations in the range of 5$30 \mathrm{mg} \mathrm{L}^{-1}$. The amount of $\mathrm{MO}$ adsorbed, $\mathrm{q}_{\mathrm{e}}\left(\mathrm{mg} \mathrm{g}^{-1}\right)$ was calculated by the following mass balance relationship:

$\mathrm{q}_{\mathrm{e}}=\left(\mathrm{C}_{0}-\mathrm{C}_{\mathrm{e}}\right) \mathrm{V} / \mathrm{W}$

Where $\mathrm{C}_{0}$ and $\mathrm{C}_{\mathrm{e}}$ are the initial and equilibrium dye concentrations in solution, respectively $\left(\mathrm{mg} \mathrm{L}^{-1}\right), \mathrm{V}$ the volume of the solution $(L)$ and $W$ is the mass $(g)$ of the adsorbent used.

Preparation of $A g-N P-A C$

The Ag nanoparticle was synthesized in a one-step reduction process in an aqueous solution under nitrogen atmosphere. $400 \mu \mathrm{L}$ aliquot of $0.1 \mathrm{M} \mathrm{AgNO}_{3}$ aqueous solution was added into $100 \mathrm{~mL}$ of containing $0.15 \mathrm{w} / \mathrm{w} \%$ of the soluble starch solution and vigorously stirred for 1 $\mathrm{h}$. The $\mathrm{pH}$ of resulting solution was adjusted to 8.0 by addition of $0.1 \mathrm{M} \mathrm{NaOH}$ solution. Under these experimental conditions, the initial reaction mixture was colourless and the growth of the $\mathrm{Ag}$ nanoparticles was monitored at different time intervals using UV-Vis absorption spectroscopy. After about $1 \mathrm{~h}$, the light yellow colour shows the start of formation of the $\mathrm{Ag}$ nanoparticles. The mixture was maintained at $50{ }^{\circ} \mathrm{C}$ for $24 \mathrm{~h}$ and the colour of the reaction solution became yellow. Appropriate aliquots of the $\mathrm{Ag}$ nanoparticles solution was mixed with $A C$ in a large and open Erlenmeyer under magnetic stirring for up to $10 \mathrm{~h}$, resulting in the deposition of the Ag nanoparticles on the activated carbon. The carbon-supported Ag nanoparticles were then filtered and extensively washed with double

Fig. 2. Temporal evolution of UV-visible absorption spectra after addition of $\mathrm{AgNO}_{3}$ solution into soluble starch solution at $50^{\circ} \mathrm{C}$

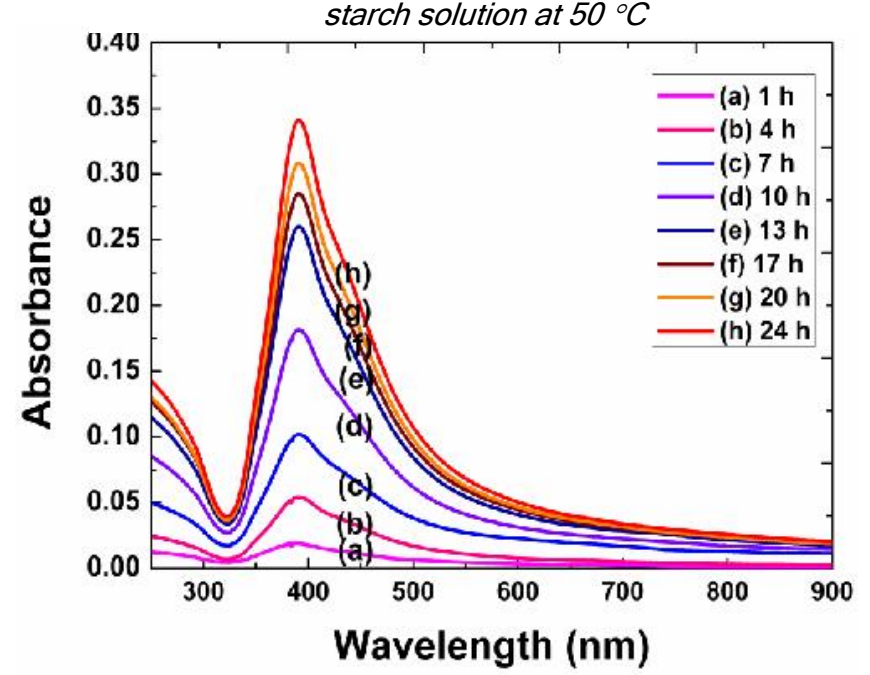

Research article

CIndian Society for Education and Environment (iSee)

"Methods of analysing missing values in a regression model"

http://www.indjst.org distilled water. The filtrate solutions were analyzed for the $\mathrm{Ag}$ nanoparticle using FAAS. A mortar was used to homogeneously ground the carbon-supported $\mathrm{Ag}$ nanoparticles powder and the proposed sorbent were stored in air at room temperature and were found to have a shelf life of at least 1 year.

Results and discussion

Characterization of adsorbent

Fig. 2 shows the UV-Vis absorption spectra obtained at different time intervals after mixing $\mathrm{AgNO}_{3}$ aqueous solution with soluble starch aqueous solution at $50{ }^{\circ} \mathrm{C}$. Formation of $\mathrm{Ag}$ nanoparticles in the colloidal solution was monitored from their absorption spectra as the small noble metal particles reveal absorption band in the UVVis spectral region due to surface Plasmon resonance (SPR) (Huang \& Yang, 2004). The reduction of the $\mathrm{Ag}^{+}$ ions starch is a slow process and until $1 \mathrm{~h}$ broad absorption band (maximum at about $400 \mathrm{~nm}$ ) was achieved that related to the SPR of Ag nanoparticles that show high polydispersity (in size and shape) of the $\mathrm{Ag}$ particles. The intensity of the SPR band increased

Fig.3. X-ray diffraction pattern of the starchstabilized Ag nanoparticles

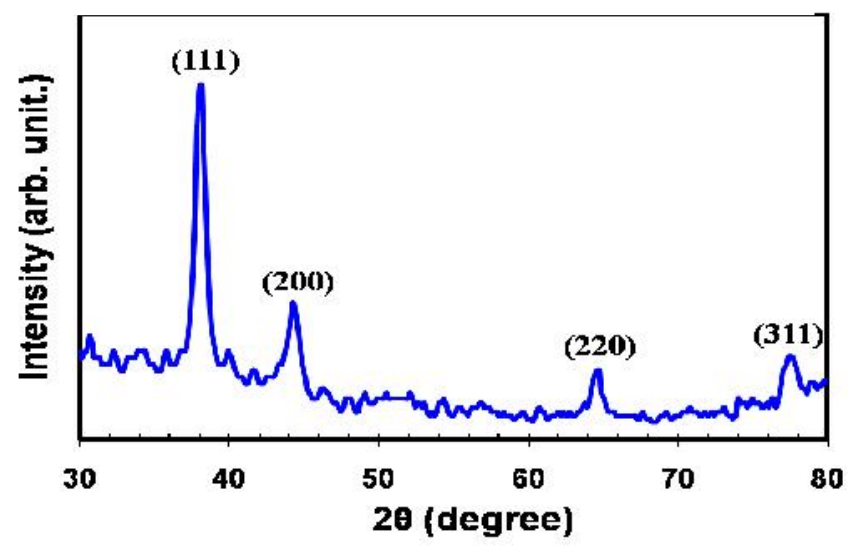

systematically with the increase of reaction time and reach constant maximum value after about $24 \mathrm{~h}$ stability of $\mathrm{Ag}$ nanoparticle obtained via its. The reduction with starch aqueous solution at $50{ }^{\circ} \mathrm{C}$ for several months' show that starch serves as both reducing and protecting agent. X-ray diffraction (XRD) pattern of silver nanoparticles powder (Fig. 3) exhibits peaks at $2 \theta$ angles of $38.17,44.21,64.32$, and 77.12 that correspond to the [111], [200], [220], and [311] crystal planes of a cubic lattice structure of silver nanoparticles, respectively (Wang \& Chen, 2008). From the full-width at halfmaximum of diffraction peaks, the average size of the silver nanoparticles based on Debye-Scherrer equation (Goudarzi et al., 2009) was the calculated that average size of $\mathrm{Ag}$ nanoparticles was around $55 \mathrm{~nm}$. The FESEM image of the $\mathrm{Ag}$ nanoparticles is shown in Fig. 4, which reveals that the $\mathrm{Ag}$ nanoparticles are semi-spherical in shape and uniform in size distribution. The size of each $\mathrm{Ag}$ nanoparticle is in the range of $15-80 \mathrm{~nm}$. The particle 
size measured directly from this FESEM image agrees with that determined by the XRD results.

\section{Effect of contact time}

Equilibrium time is one of the most important parameters in the design of economical wastewater treatment systems. The adsorption of MO onto Ag-NP-AC at various initial concentrations was studied as a function of contact time in order to determine the necessary adsorption equilibrium time. Fig. 5 (the effects of contact time) shows the rapid adsorption at the initial contact time due to the high available surface of Ag-NP-AC. The contact time's needs for $\mathrm{MO}$ solutions to reach equilibrium were 15 and $18 \mathrm{~min}$ for 10 and $20 \mathrm{mg} \mathrm{L}^{-1} \mathrm{MO}$ concentration, respectively. It was also seen that an increase in initial dye concentrations resulted in increased dye uptake. The adsorption capacity at equilibrium $\left(\mathrm{q}_{\mathrm{e}}\right)$ increased from 24.70 to $32.99 \mathrm{mg} \mathrm{g}^{-1}$ with an increase in the initial $\mathrm{MO}$ concentrations from 10 to $20 \mathrm{mg} \mathrm{L}^{-1}$.In addition, the curves are single, smooth and continuous towards saturation, indicating the formation of monolayer coverage of dye molecules on Ag-NP-AC surface (Malik ,2003 \& Fana et al., 2009). The studies involving different contact times help in determining the uptake capacities of the dye at varying time intervals keeping the amount of the adsorbents fixed at room temperature.

\section{Effect $\mathrm{pH}$ on $\mathrm{MO}$ adsorption efficiency}

$\mathrm{pH}$ plays an important role in the dye adsorption. To study the effect of solution $\mathrm{pH}$ on $\mathrm{MO}$ adsorption, $10 \mathrm{mg}$ $\mathrm{L}^{-1}$ of solution was agitated with $0.02 \mathrm{~g}$ of Ag-NP-AC for 15 min at different $\mathrm{pH}$ values (2.0-9.0) at $25^{\circ} \mathrm{C}$ and the results are shown in Fig. 6. An increase in the adsorption of $\mathrm{MO}$ was found with increasing $\mathrm{pH}$ and maximum adsorption and removal percentage was achieved at $\mathrm{pH}$ 5.0 when the $\mathrm{pH}$ changed from 2 to 5 and removal percentage increased from $67.33 \%$ to $98.75 \%$. At low $\mathrm{pH}$ values due to the competition between $\mathrm{H}^{+}$and positively charged $\mathrm{MO}$ molecule for the available adsorption sites lower $\mathrm{q}_{\mathrm{e}}$ values were obtained. The increase of $\mathrm{MO}$ adsorption with increasing $\mathrm{pH}$ values can be explained by the electrostatic interaction between the cationic dye and the negatively charged Ag-NP-AC at high $\mathrm{pH}$ values. Beyond $\mathrm{pH}$ 5.0, the extent of adsorption was observed to slightly decrease.

\section{Effect of ionic strength}

The dyes adsorption would be affected by the salt concentration on the hydrophobic and electrostatic interaction between dye and surface functional adsorptive sites of the Ag-NP-AC. lonic strength influence on both electrostatic and non-electrostatic interactions between the adsorbate and the adsorbent surface (Chiou \& Li, 2002). To determine whether the on-going $M O$ adsorption process over Ag-NP-AC was affected by salt (ionic strength), a set of similar experiments were undertaken at potassium chloride concentrations in the range of 0 to 3 mol. $\mathrm{L}^{-1}$ at while other variables was set at $10 \mathrm{mg} \mathrm{L}^{-1}$ of $\mathrm{MO}, \mathrm{pH}$ of 5.0, adsorbent dose of $0.02 \mathrm{~g}$ and contact time of $15 \mathrm{~min}$. The adsorption capacities of Ag-NP-AC for dye
Vol. 5 No. 3 (Mar 2012)

ISSN: 0974- 6846

Fig.5. Effect of contact time on MO removal by 0.02 and $0.03 \mathrm{~g}$ of $\mathrm{Ag}-\mathrm{NP}-\mathrm{AC}$ in $50.0 \mathrm{ml}, \mathrm{pH} 5$, at room temperature and MO concentration 10.0 and $20.0 \mathrm{mg} \mathrm{L}^{-1}$ respectively.

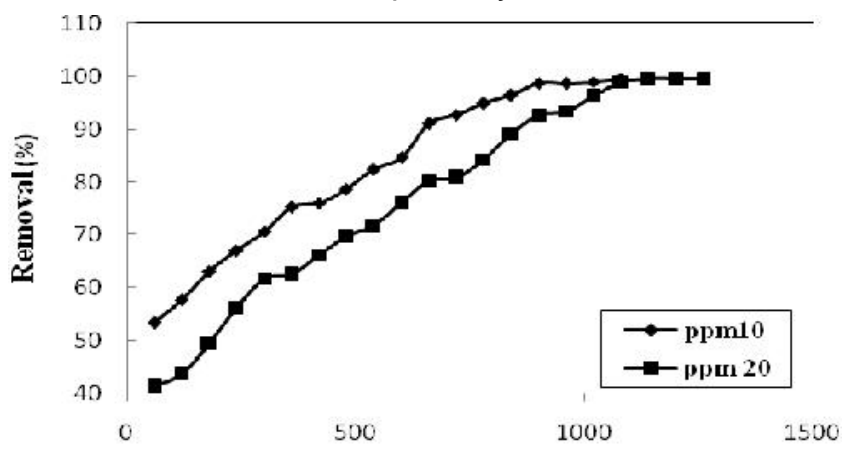

Time(s)

Fig.6. Effect of $p H$ on the removal of MO by Ag-NP-AC at room temperature, contact time of $15 \mathrm{~min}$, adsorbent dosage of $0.02 \mathrm{~g}$ in $50.0 \mathrm{ml}$ and dye concentration of 10.0

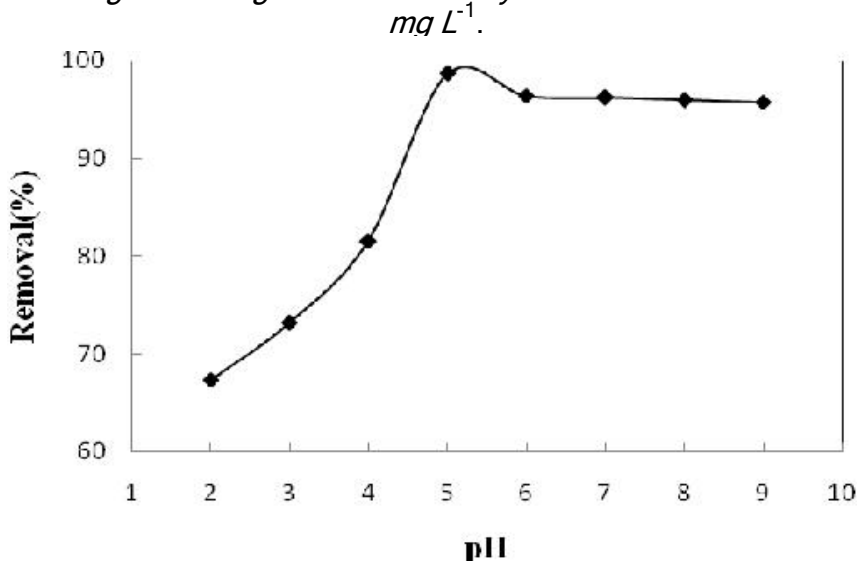

Fig. 7. Effect of Ag-NP-AC dosage on MO removal at dye concentration of $10.0 \mathrm{mg} \mathrm{L}^{-1}$ in $50.0 \mathrm{ml}$, at $\mathrm{pH}$, and room temperature.

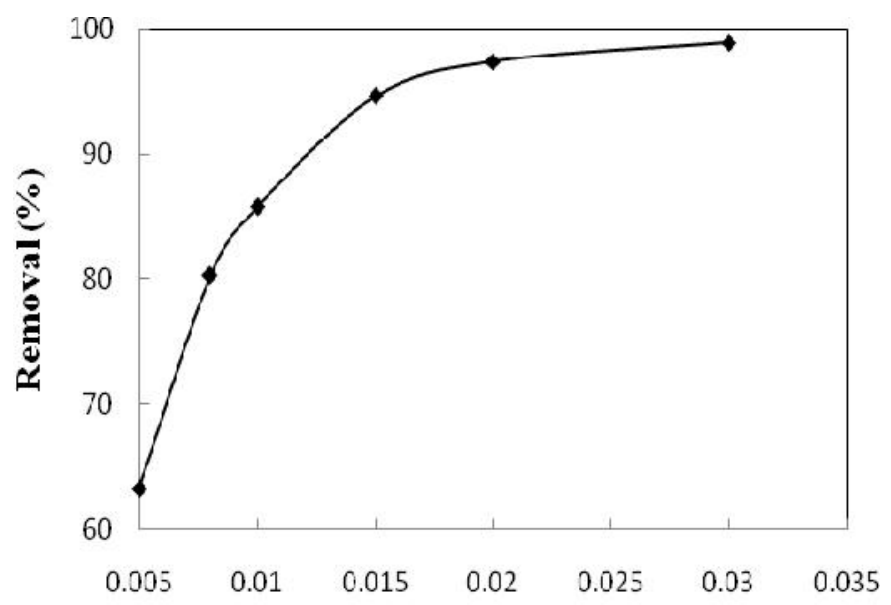

Amount of adsorbent (g)

were affected with increasing $\mathrm{KCl}$ concentration from 0 to 2 mol.L ${ }^{1}$. Effect of adsorbent dose on dye adsorption
Ogoke U. P. \& Nduka E. C. Indian J.Sci.Technol. 
The amount of adsorbent has important influence on the adsorption and removal percentage and determines the capacity of adsorbent for given initial concentration. The effect of amount of Ag-NP-AC on the MO removal percentage (Fig. 7) show that the initial removal percentage increase rapidly with the raising the Ag-NP$\mathrm{AC}$ and after $0.02 \mathrm{~g}$, the removal percentage almost reach constant maximum value. The $\mathrm{MO}$ removal percentage increase to $98.97 \%$ with the raising the amount of adsorbent from 0.005 to $0.02 \mathrm{~g}$. The increase in dye removal percentage is due to increased available adsorption surface such as silver atom and $A C$ functional group and the availability of more adsorption sites. When the adsorbent dose was increased to $0.02 \mathrm{~g}$, the ratio of $\mathrm{MO}$ adsorbed to adsorbent showed no significant difference. Therefore, $0.02 \mathrm{~g}$ was chosen for later removal studies.

\section{Effect of initial MO concentration}

The dye in the effluent of different industries may have different concentrations, which raises the question of how different dye concentrations influence the performance of Ag-NP-AC for MO removal in adsorption process, the dye molecules successfully diffuse and adsorbed to the adsorbent surface and gradually penetrate to the boundary layer. Therefore, higher concentration of $\mathrm{MO}$ will require more time to attain equilibrium (Hameed et al., 2008). Effect of MO initial concentration on the efficiency of its adsorption was investigated in the range of 5 to $30 \mathrm{mg} \mathrm{L}^{-1}$ and results are shown in Fig. 8. Although, by increasing the initial dye concentration the percentage of dye removal decreased, the actual amount of dye adsorbed per unit mass of Ag-NP-AC increase.

Adsorption isotherms

Equilibrium data, commonly known as adsorption isotherms, describe how the adsorbate interacts with adsorbents and give a comprehensive understanding of the nature of interaction. It is basically important to optimize the design of an adsorption system. The parameters obtained from the different models provide important information on the surface properties of the adsorbent and its affinity of adsorbate. Several conventional isotherm equations fitted to such a Langmuir, Freundlich and Tempkin.

The Langmuir isotherm is based on the assumption that the adsorption process takes place at specific homogeneous sites within the adsorbent surface and that once a dye molecule occupies a site no further adsorption can take place at that site, leading to the conclusion that the adsorption is a monolayer process in nature (Langmuir, 1916; El-Geundi, 1991 \& Hameed, 2009).

The equation of Langmuir isotherm is represented as follows:

$\mathrm{q}_{\mathrm{e}}=\mathrm{K}_{\mathrm{L}} \mathrm{Q}_{\mathrm{m}} \mathrm{C}_{\mathrm{e}} /\left(1+\mathrm{K}_{\mathrm{L}} \mathrm{C}_{\mathrm{e}}\right)$

Where $C_{e}$ is the equilibrium concentration $\left(\mathrm{mg} \mathrm{L}^{-1}\right), \mathrm{q}_{e}$ is the amount of adsorbents sorbet per unit mass of adsorbent at equilibrium $\left(\mathrm{mg} \mathrm{g}^{-1}\right), \mathrm{Q}_{\mathrm{m}}$ is the theoretical maximum adsorption capacity $\left(\mathrm{mg} \mathrm{g}^{-1}\right), \mathrm{K}_{\mathrm{L}}$ is the Langmuir
Vol. 5 No. 3 (Mar 2012)

ISSN: 0974- 6846

Fig.8. Effect of initial dye concentration on removal of $\mathrm{MO}$ at $0.02 \mathrm{~g}$ of $\mathrm{Ag}-\mathrm{NP}-\mathrm{AC}$ in $50.0 \mathrm{ml}, \mathrm{pH}=5.0$ and room temperature

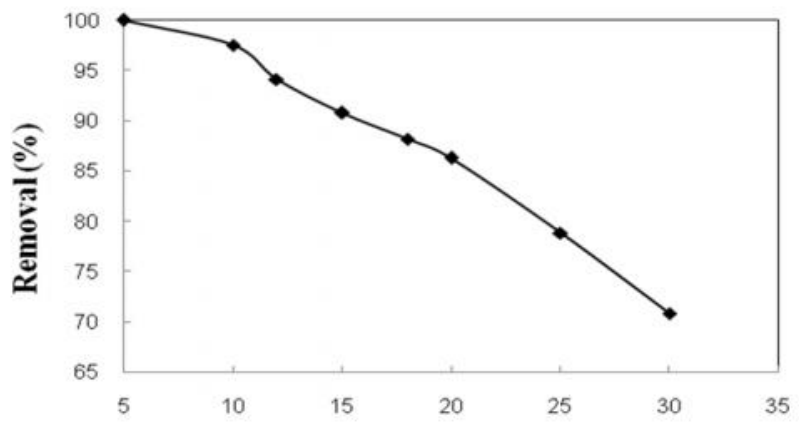

Initial dye concentration $(\mathrm{mg} / \mathrm{L})$

Fig.9. Langmuir isotherm for adsorption of MO onto $0.02 \mathrm{~g}$ of Ag-NP-AC in $50.0 \mathrm{~m} /$ of different initial dye concentration, room temperature, $\mathrm{pH}=5.0$.

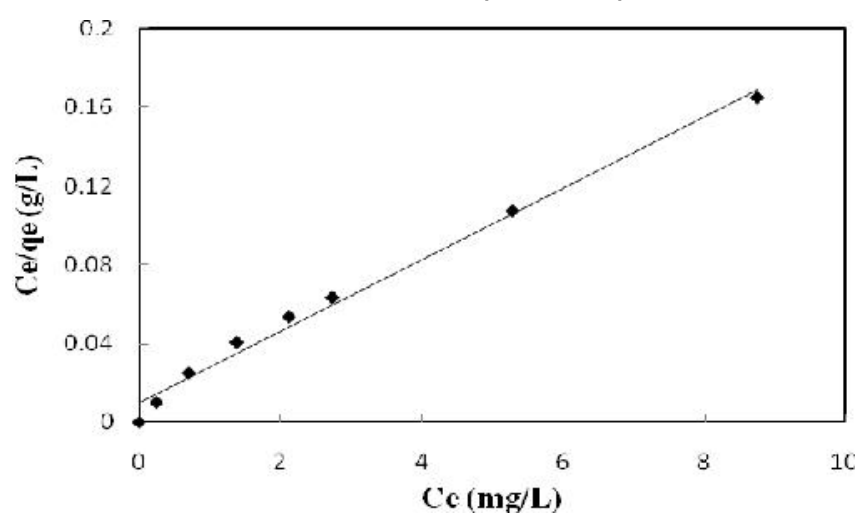

Fig. 10. Plot of pseudo-second-order kinetics for adsorptionof MO onto 0.02 and $0.03 \mathrm{~g}$ of $\mathrm{Ag}-\mathrm{NP}-\mathrm{AC}$ in

$50 \mathrm{ml}$ at $\mathrm{pH}=5.0$, at room temperature and dye concentration of 10.0 and $20.0 \mathrm{mg} \mathrm{L}^{-1}$ respectively.

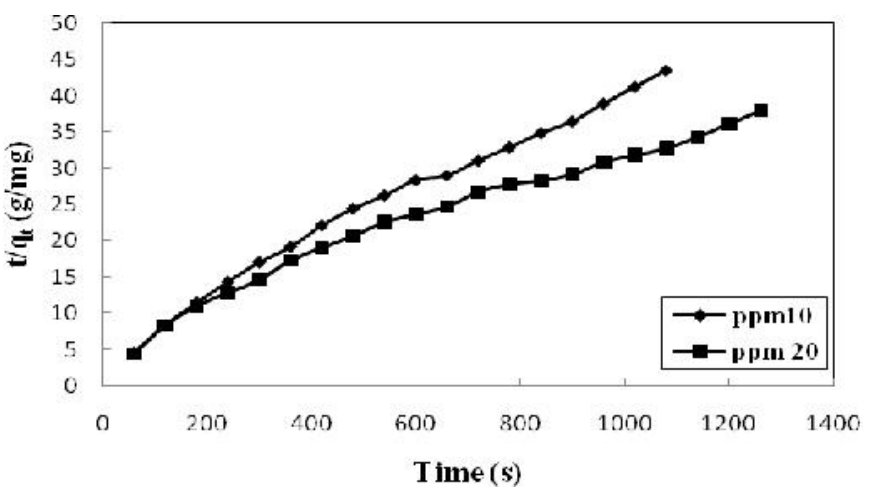

isotherm constant related to the energy of adsorption ( $L$ $\left.\mathrm{mg}^{-1}\right)$. A well-known linear expression for the Langmuir isotherm is represented as follows:

$$
1 / q_{e}=1 / Q_{m}+1 / K_{L} Q_{m} C_{e}
$$

The values of $K_{L}$ and $Q_{m}$ can be determined from the slope and intercept of the linear plot of $C_{e} / q_{e}$ versus $C_{e}$ (Fig. 9). 
The Freundlich isotherm is an empirical equation assuming that the adsorption process takes place on a heterogeneous surface through a multilayer adsorption mechanism and adsorption capacity is related to the concentration of dye at equilibrium (El-Geundi 1991).

The Freundlich equation is given as follows:

$\mathrm{q}_{\mathrm{e}}=\mathrm{K}_{\mathrm{F}} \mathrm{C}_{\mathrm{e}}{ }^{1 / \mathrm{nF}}$

where $\mathrm{q}_{\mathrm{e}}$ is the amount of adsorbed dye at equilibrium $(\mathrm{mg} / \mathrm{g}), C_{e}$ is the equilibrium concentration of the adsorbate $(\mathrm{mg} / \mathrm{L}), \mathrm{K}_{\mathrm{F}}$ is the Freundlich adsorption constant related to adsorption capacity of the adsorbent $\left((\mathrm{mg} / \mathrm{g})(\mathrm{L} / \mathrm{mg})^{1 / \mathrm{n}}\right)$, and $1 / \mathrm{n}_{\mathrm{F}}$ is the adsorption intensity. A linear form of the Freundlich equation is generally expressed as follows:

$\ln \mathrm{q}_{\mathrm{e}}=\ln \mathrm{K}_{\mathrm{F}}+\left(1 / \mathrm{n}_{\mathrm{F}}\right) \ln \mathrm{C}_{\mathrm{e}}$

The values of $K_{F}$ and $1 / n_{F}$ were calculated from the intercept and slope of the plot of $\ln \mathrm{q}_{\mathrm{e}}$ versus $\ln \mathrm{C}_{\mathrm{e}}$.

Tempkin isotherm takes into account the effects of indirect adsorbate-adsorbate interactions on adsorption, and suggests that the heat of adsorption of all the molecules in the layer would decrease linearly with coverage due to these interactions (Hameed, 2009). The linear form of Tempkin isotherm is expressed as follows:

$$
\mathrm{q}_{\mathrm{e}}=\mathrm{B}_{\mathrm{T}} \ln \mathrm{A}_{\mathrm{T}}+\mathrm{B}_{\mathrm{T}} \ln \mathrm{C}_{\mathrm{e}}
$$

Where $B_{T}$ is the Tempkin constant related to heat of adsorption and $A_{T}$ is he equilibrium binding constant $\left(\mathrm{L} \mathrm{mg}^{-}\right.$ $\left.{ }^{1}\right)$. The constants $A_{T}$ and $B_{T}$ can be determined by a plot of $\mathrm{q}_{\mathrm{e}}$ versus $\ln \mathrm{C}_{\mathrm{e}}$

Table1. Isotherm parameters and correlation coefficients calculated by various adsorption models onto $0.4 \mathrm{~g} \mathrm{~L}^{-1}$ of

Ag-NP-AC, $p H$ 5.0, and room temperature.

\begin{tabular}{|c|c|c|}
\hline Isotherm equation & Parameters & Value \\
\hline \multirow{3}{*}{$\mathrm{C}_{\mathrm{e}} / \mathrm{q}_{\mathrm{e}}=\left(1 / \mathrm{K}_{\mathrm{L}} \mathrm{Q}_{\mathrm{m}}\right)+\mathrm{C}_{\mathrm{e}} / \mathrm{Q}_{\mathrm{m}}$} & $\mathrm{Q}_{\mathrm{m}}(\mathrm{mg} / \mathrm{g})$ & 55.54 \\
\cline { 2 - 3 } & $\mathrm{K}_{\mathrm{L}}\left(\mathrm{L} \mathrm{mg}^{-1}\right)$ & 2.00 \\
\hline & $\mathrm{R}^{2}$ & 0.990 \\
\cline { 2 - 3 } Freundlich: & $1 / \mathrm{n}_{\mathrm{F}}$ & 0.157 \\
\cline { 2 - 3 } In $\mathrm{q}_{\mathrm{e}}=\operatorname{In} \mathrm{K}_{\mathrm{F}}+\left(1 / \mathrm{n}_{\mathrm{F}}\right) \ln \mathrm{C}_{\mathrm{e}}(\mathrm{L} / \mathrm{mg})$ & 34.59 \\
\hline & $\mathrm{R}^{2}$ & 0.954 \\
\hline & $\mathrm{B}_{\mathrm{T}}$ & 4.22 \\
\hline $\mathrm{q}_{\mathrm{e}}=\mathrm{B}_{\mathrm{T}} \ln \mathrm{A}_{\mathrm{T}}+\mathrm{B}_{\mathrm{T}} \ln \mathrm{C}_{\mathrm{e}}$ & $\mathrm{A}_{\mathrm{T}}(\mathrm{L} / \mathrm{mg})$ & 25.70 \\
\cline { 2 - 3 } & $\mathrm{R}^{2}$ & 0.826 \\
\hline
\end{tabular}

For the adsorbent, Langmuir, Freundlich and Tempkin isotherms were studied, and their constants were calculated (Won et al., 2006). The best fitted model was selected based on the determination coefficient $\left(R^{2}\right)$. The data from the isotherm evaluation is summarized in Table 1. Based on the information in Table 1 , the $R^{2}$ of the Langmuir isotherm model was higher than the other fitted models show that the experimental equilibrium data was better explained by the Langmuir equation. This finding supports the assumption that the $\mathrm{MO}$ is adsorbed homogeneous monolayer onto Ag-NP-AC particles sites and has a free-energy change for all adsorption sites (Jarvi et al., 2005).
Vol. 5 No. 3 (Mar 2012)

ISSN: 0974- 6846

Table 2. Adsorption kinetic parameters at different initial MO onto $0.40 \mathrm{~g} \mathrm{~L}^{-1}$ of $A g-N P-A C$ at $p H 5.0$, room temperature and MO concentration of 10.0 and 20.0 $m g L^{-1}$.

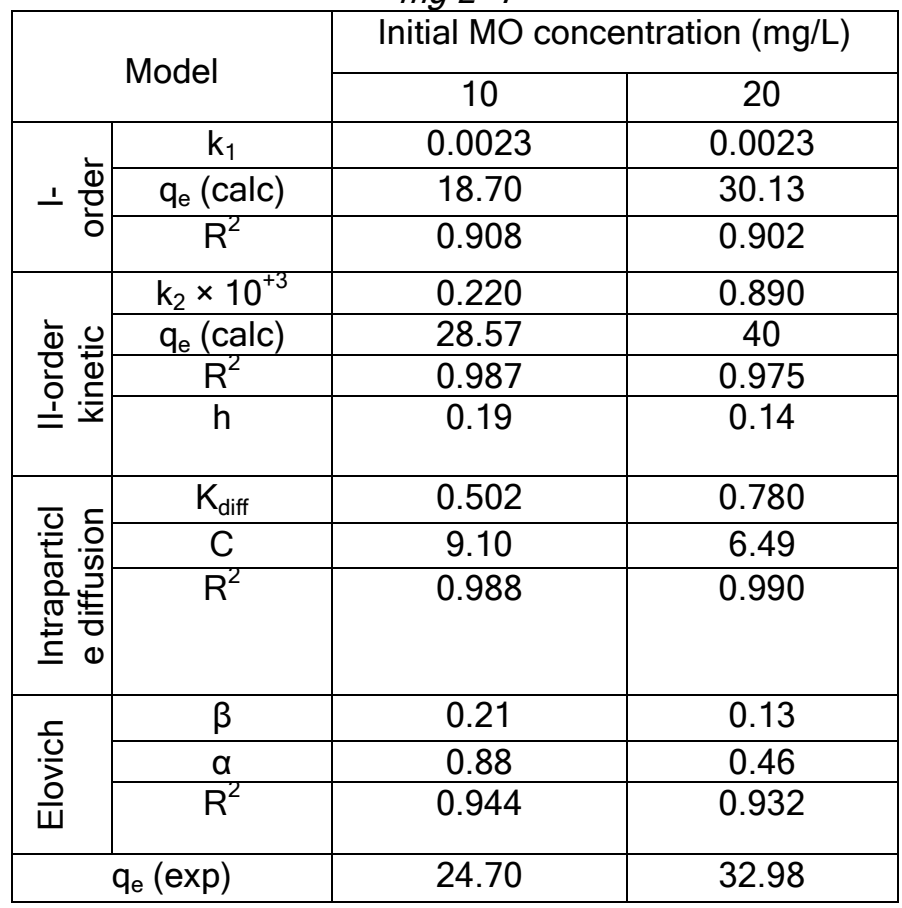

\section{Adsorption kinetics}

One of the essential requirements for the proper interpretation of the experimental data obtained during kinetic studies is to identify the step (s) governing overall rate of removal during the adsorption process (Ruthven \& Loughlin, 1971: Pignatello et al., 1993 \& Arami et al., 2006).

The kinetics of adsorption indicates the factor control the efficiency of the process and the equilibrium time and show the rate of adsorbate uptake on Ag-NP-AC. To identify the potential rate involve in the process of adsorption four kinetic models were applied for fitting the experimental data of the dye adsorption including pseudofirst and second-order, Elovich kinetic as well as intraparticle diffusion models.

The pseudo-first-order kinetic model can be represented by the Lagergren rate equation (Lagergren, 1898):

$\log \left(\mathrm{q}_{\mathrm{e}}-\mathrm{q}_{\mathrm{t}}\right)=\log \mathrm{q}_{\mathrm{e}}-\left(\mathrm{k}_{1} / 2.303 \mathrm{t}\right)$

Where $\mathrm{q}_{\mathrm{e}}$ and $\mathrm{q}_{\mathrm{t}}$ are the amounts of adsorbed dye $(\mathrm{mg} / \mathrm{g})$ at equilibrium and at contact time $\mathrm{t}(\mathrm{min})$, respectively, and $\mathrm{k}_{1}$ is the pseudo-first-order rate constant $\left(\min ^{-1}\right)$.

The values of $\mathrm{q}_{\mathrm{e}}$ and $\mathrm{k}_{1}$ for the pseudo-first-order kinetic model were determined from the intercepts and the slopes of the plots of $\log \left(q_{e}-q_{t}\right)$ versus $t$, respectively (not shown). The $k_{1}$ values, correlation coefficient values and $\mathrm{q}_{\mathrm{e}}$ values (experimental and calculated ones) are summarized in Table 2 . The experimental $\mathrm{q}_{\mathrm{e}}$ values, $\mathrm{q}_{\mathrm{e} \text {,exp }}$, were not close to the calculated ones, $\mathrm{q}_{\mathrm{e}, \mathrm{cal}}$, obtained from 
Indian Journal of Science and Technology

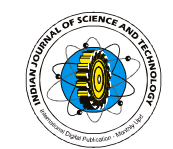

Table 3. Comparison of performance of proposed method with previously reported methyl orange (MO) removal.

\begin{tabular}{|c|c|c|c|c|c|c|c|}
\hline Absorbent & $\begin{array}{l}\text { Stirring } \\
\text { Time } \\
\text { (min) }\end{array}$ & $\begin{array}{c}\text { Amount of } \\
\text { absorbent }(\mathrm{g})\end{array}$ & $\begin{array}{c}\mathrm{Q}_{\mathrm{m}}\left(\mathrm{mg} \cdot \mathrm{g}^{-1}\right) \\
\text { at } 303 \mathrm{~K}\end{array}$ & $\mathrm{pH}$ & Kinetic & Isotherm & References \\
\hline $\begin{array}{c}\text { Ultrafine } \\
\text { Coal Powder }\end{array}$ & 240 & 0.10 & 18.50 & 4.13 & \begin{tabular}{|c|}
$\begin{array}{c}\text { Pseudo second- } \\
\text { order }\end{array}$ \\
\end{tabular} & Freundlich & 5 \\
\hline $\begin{array}{c}\text { Activated carbon } \\
\text { derived from } \\
\text { Phragmites australis }\end{array}$ & 240 & 0.05 & 217.40 & 3 & $\begin{array}{l}\text { Pseudo second- } \\
\text { order }\end{array}$ & Tempkin & 25 \\
\hline Bottom Ash & 380 & 0.10 & 3.60 & 3 & particle diffusion & $\begin{array}{c}\text { Langmuir } \\
\text { and Freundlich }\end{array}$ & 13 \\
\hline Soya oil industries & 150 & 0.05 & 16.70 & 3 & film diffusion & $\begin{array}{c}\text { Langmuir } \\
\text { and Freundlich }\end{array}$ & 13 \\
\hline $\begin{array}{c}\text { Nanoscale } \\
\text { zerovalent iron } \\
\text { particles }\end{array}$ & 60 & & & 9 & $\begin{array}{l}\text { Pseudo first } \\
\text { order }\end{array}$ & & 37 \\
\hline $\begin{array}{l}\text { Multiwalled carbon } \\
\text { nanotubes } \\
\text { (MWCNT) }\end{array}$ & 22 & 0.03 & 88.50 & 4 & $\begin{array}{l}\text { Pseudo second- } \\
\text { order }\end{array}$ & Langmuir & \multirow{2}{*}{$\begin{array}{l}\text { Present } \\
\text { work }\end{array}$} \\
\hline $\begin{array}{c}\text { Activated carbon } \\
(A C)\end{array}$ & 98 & 0.80 & 3.10 & 2 & $\begin{array}{l}\text { Pseudo second- } \\
\text { order }\end{array}$ & Langmuir & \\
\hline
\end{tabular}

the linear plots. It suggests that the kinetics of $\mathrm{MO}$ adsorption on Ag-NP-AC did not follow the pseudo-firstorder kinetic model and, hence, are not diffusioncontrolled phenomena (Table 2).

Pseudo-second-order kinetic model: The pseudo-secondorder kinetic model (Fig.10) can be represented in the following form:

$\mathrm{t} / \mathrm{q}_{\mathrm{t}}=\left(1 / \mathrm{k}_{2} \mathrm{q}_{\mathrm{e}}^{2}\right)+\left(1 / \mathrm{q}_{\mathrm{e}}\right) \mathrm{t}$

Where $k_{2}$ is the rate constant of pseudo-second-order adsorption ( $\mathrm{g} /(\mathrm{mg} \mathrm{min}))$.

The plot of $t / q_{t}$ versus $t$ is a straight line (Fig. 10) and $k_{2}$ and $q_{e}$ values determined from the slopes and intercepts of the plot are presented in Table 2 along with the corresponding correlation coefficients. This procedure is more likely to predict the behavior over the whole range of adsorption. The linear plot shows good agreement between experimental and calculated $\mathrm{q}_{\mathrm{e}}$ values (Table 2). Besides, the corresponding correlation coefficients $\left(R^{2}\right)$ for the pseudo-second- order kinetic model $\left(R^{2}=0.990\right)$ indicated the applicability of the pseudo-second-order kinetic model to describe the adsorption process of $\mathrm{MO}$ on Ag-NP-AC adsorbents suggesting that adsorption process was controlled by adsorption (Arami et al., 2006). The pseudo-second-order kinetic parameters obtained could be used to determine the equilibrium adsorption capacity (percentage of the removal of $\mathrm{MO}$ ) rate constants and initial sorption rate for a reactor design (Table 2).

Elovich equation: Elovich equation is one of the most useful models for describing adsorption, which is expressed as follows:

$q_{t}=(1 / \beta) \ln (\alpha \beta)+(1 / \beta) \ln (t)$

Where $\alpha$ is the initial adsorption rate $(\mathrm{mg} / \mathrm{g} \mathrm{min})$ ), and $\beta$ is the desorption constant related to the extent of surface coverage and activation energy for adsorption $(\mathrm{g} / \mathrm{mg})$. The parameters $(1 / \beta)$ and $(1 / \beta) \ln (\alpha \beta)$ can be calculated from the slope and intercept of the linear plot of $q_{t}$ versus In $t$. (Table 2) (Tseng, 2006).

Intraparticle diffusion model: Generally, intraparticle diffusion model is one of the efficient models for evaluation of adsorption kinetics for most processes, where uptake varies almost proportionally with $t^{1 / 2}$ rather than with the contact time t (Hameed et al., 2008). According to this theory, the intraparticle diffusion equation is expressed as follows:

$\mathrm{q}_{\mathrm{t}}=\mathrm{k}_{\mathrm{diff}} \mathrm{ft}^{1 / 2}+\mathrm{C}$

Where $k_{\text {diff }}$ is the intraparticle diffusion rate constant ( $\mathrm{mg} / \mathrm{g} \mathrm{min}^{1 / 2}$ ) and $\mathrm{C}$ is the intercept. If the mechanism of adsorption process follows the intraparticle diffusion, the plot of $q_{t}$ versus $t^{1 / 2}$ would be a straight line and $k_{\text {diff }}$ and $C$ can be calculated from the slope of the plot (Fig. 11). Values of $\mathrm{C}$ give an idea about the thickness of boundary layer, i.e., the larger the intercept, the greater the

Fig. 11. Plot of intraparticle diffusion kinetics modelfor adsorption of $M O$ onto 0.02 and $0.03 \mathrm{~g}$ of $\mathrm{Ag}-\mathrm{NP}-\mathrm{AC}$ in 50.0 mlat $\mathrm{pH}=5.0$, at room temperature and dye concentration of 10.0 and $20.0 \mathrm{mg} \mathrm{L}^{-1}$ respectively.

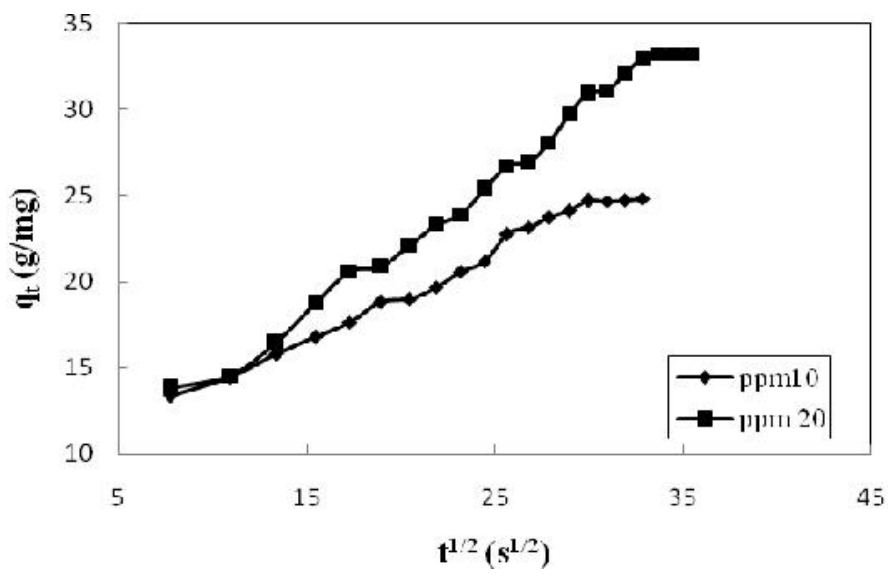


contribution of the surface sorption in the rate-controlling step (Kavitha \& Namasivayam, 2007; Demirbas \& Nas, 2009).

The first section of plots indicates that boundary layer diffusion probably limited $\mathrm{MO}$ adsorption (Dizage et al.,2008) The second section shows the occurrence of intraparticle diffusion as the adsorption limiting step (Valix et al., 2004). Fig. 11 also illustrates that, for higher MO concentrations, the contribution of boundary layer diffusion decreases, whereas the time period during which the intraparticle diffusion is the adsorption rate limiting factor is longer. Another important point found in Fig. 11 is the increase of slope of both sections of plots with the increase of the MO concentration, showing that the influence of the rate-limiting step is more pronounced for higher dye concentrations. Fig. 11 shows the amount of dye adsorbed versus $t^{1 / 2}$ for different initial dye concentrations. Plots are not linear over the whole time range, which indicates that more than one mode of adsorption, is involved in dye adsorption. As already mentioned, the adsorption mechanism for any dye removal by an adsorption process may be assumed to involve the following 4 steps: (i) bulk diffusion; (ii) film diffusion; (iii) pore diffusion or intraparticle diffusion; (iv) adsorption of dye on the sorbent surface (Khaled et al., 2009). It has been demonstrated in the literature that the first step could be "neglected" if a sufficient speed of stirring was used. For intraparticle diffusion plots, the first portion indicates a boundary layer effect at the initial stage of the adsorption. The second portion of linear curve (shown in Fig. 11) is the gradual adsorption stage where intraparticle diffusion is rate-limiting. In some cases, the third portion exists, which is the final equilibrium stage where intraparticle diffusion starts to slow down due to the extremely low adsorbate concentrations left in the solutions (Cheung et al., 2007). The values of $k_{\text {diff }}$ and $C$ were obtained from the second linear portion. Table 2 shows the calculated intraparticle diffusion parameters for the adsorption process. With reference to Fig. 11, there was a linear relationship over a period of time, but they did not pass through the origin suggesting that intraparticle diffusion was present, but not the only ratecontrolling step, and that some other mechanism might be involved (Table 2) (Khaled et al.,2009).

\section{Conclusion}

The Ag-NP-AC is effective adsorbents for the removal of $\mathrm{MO}$ from aqueous solutions. Adsorption parameters for the Langmuir, Freundlich and Tempkin isotherms were determined, and the equilibrium data were best described by the Langmuir isotherm model. The adsorption kinetics can be successfully fitted to pseudo-second-order kinetic model. The results of the intraparticle diffusion model suggested that intraparticle diffusion was not the only rate-controlling step (Chen et al., 2010). Comparison of characteristics performance of proposed method with some previous MO removal reports
(Table 3) show the priority of the method in terms of lower equilibrium time, higher adsorption capacity etc.

\section{Reference}

1. Arami M, Limaee N Y Mahmoodi NM and Tabrizi NS (2006) Equilibrium and kinetics studies for the adsorption of direct and acid dyes from aqueous solution soy meal hull. J. Hazard. Mater. B, 135, 171179.

2. Barhon Z, Belhaj M, Albizane A, Azzi M, Saffaj M, Bennazha J and Younssi SA (2009) Effect of activation of zirconium phosphate by zinc salt: application to photodegradation of methyl orange. Fresen. Environ. Bull. 18, 2323-2327.

3. Chang RW, Chadwick J, Allison JC, Hayes YO, Talley DL and Autry CE (1994) Microbial succession and intestinal enzyme activities in the developing rat. $J$. Appl. Bacteriol. 77, 709-718.

4. Chen S, Zhang J, Zhang C, Yue Q, Li Y and Li C (2010) Equilibrium and kinetic studies of methyl orange and methyl violet adsorption on activated carbon derived from Phragmites australis. Desalination. 252, 149-156.

5. Chen Z, Jin XY, Megharaj M and R Naidu (2011) Removal of methyl orange from aqueous solution using bentonite-supported nanoscale zero-valent iron. J. Colloid, Interface Sci. 363, 601-607.

6. Cheung WH, Szeto YS and McKay G (2007) Intraparticle diffusion processes during acid dye adsorption onto chitosan. Bioresour. Technol. 98, 2897-2904.

7. Chiou MS and Li HY (2002) Equilibrium and kinetic modeling of adsorption of reactive dye on cross-linked chitosan beads, J. Hazard. Mater. B 93, 233-248.

8. Chung KT (1983) The significance of azo-reduction in the mutagenesis and carcinogenesis of azo dyes. Mutat. Res. 114, 269-281.

9. Chung KT, Stevens JSE and Cerniglia CE (1992) The reduction of azo dyes by the intestinal microflora. Crit. Rev. Microbiol. 18, 175-190.

10.Demirbas E and Nas MZ (2009) Batch kinetic and equilibrium studies of adsorption of reactive Blue 21 by fly ash and sepiolite. Desalination. 243, 8-21.

11.Dizage N, Aydiner C, Demirbas E, Kobya M and Kara $S$ (2008) Adsorption of reactive dyes from aqueous solutions by fly ash: Kinetic and equilibrium studies. $J$. Hazard. Mater. 150, 737-746.

12.EI Qada EN, Allena SJ and Walker GM (2008) Adsorption of basic dyes from aqueous solution onto activated carbons. Chem. Eng. J. 135, 174-184.

13.El-Geundi MS (1991) Color removal from textile effluents by adsorption techniques. Water Res. 25, 271-273.

14.Fana J, Guoa Y, Wanga J and Fanb M (2009) Rapid decolorization of azo dye methyl orange in aqueous solution by nanoscale zerovalent iron particles. $J$. Hazard. Mater.166, 904-910. 
15.Goudarzi A, Motedayen Aval G, Park SS, Choi MC, Sahraei R, Habib Ullah M, Avane A and Ha CS (2009) Low-Temperature Growth of Nanocrystalline MnDoped ZnS Thin Films Prepared by Chemical Bath Deposition and Optical Properties, Chem. Mater. 21, 2375-2385.

16. Hameed BH (2009) Spent tea leaves: A new nonconventional and low-cost adsorbent for removal of basic dye from aqueous solutions. J. Hazard. Mater. 161, 753-759.

17. Hameed BH, Tan IAW and Ahmad AL (2008) Adsorption isotherm, kinetic modeling and mechanism of 2, 4, 6-trichlorophenol on coconut husk-based activated carbon. Chem. Eng. J. 144, 235-244.

18. Hameed BH, Tan IAW and Ahmad AL (2008) Optimization of basic dye removal by oil palm fibrebased activated carbon using response surface methodology, J. Hazard. Mater. 158, 324-332.

19. Huang $H$ and Yang $X$ (2004) Synthesis of polysaccharide-stabilized gold and silver nanoparticles: A green method. Carbohyd. Res. 339, 2627-2631.

20.Jarvie ME, Hand DW, Bhuvendralingam S, Crittenden JC and Hokanson DR (2005) Simulating the performance of fixed-bed granular activated carbon adsorbers: Removal of synthetic organic chemicals in the presence of background organic matter, Water Research, 39, 2407-2421.

21.Jia J (2009). Removal of dyes from water by carbon nanotubes. Fresen. Environ. Bull. 18, 615-618.

22. Kadirvelu K, Kavipriya M, Karthika C, Radhika M, Vennilamani N and Pattabhi S (2003) Utilization of various agricultural wastes for activated carbon preparation and application for the removal of dyes and metal ions from aqueous solutions. Bioresour. Technol. 87, 129-132.

23. Kavitha D and Namasivayam C (2007) Experimental and kinetic studies on methylene blue adsorption by coir pith carbon. Bioresour. Technol. 98, 14-21.

24. Khaled A, Nemr A, E.El-Sikaily A and Abdelwahab O (2009) Treatment of artificial textile dye effluent containing direct yellow 12 by orange peel carbon. Desalination. 238, 210-232.

25.Kucukosmanoglu M, Gezici O and Ayar A (2006) The adsorption behaviors of methylene blue and methyl orange in a diaminoethane sporopolleninmediated column system. Sep. Purif. Technol. 52, 280-287.

26.Lagergren $S(1898)$ Zur theorie der sogenennten adsorption geloster stoffe, Kungliga .Svenska vetenskademiens. Handlingar, 24, 1-39.

27.Langmuir I (1916) The constitution and fundamental properties of solids and liquids. J. Am. Chem. Soc. 38, 2221-2295.

28. Malik PK (2003) Use of activated carbons prepared from sawdust and rice-husk for adsorption of acid dyes: a case study of Acid Yellow 36. Dyes Pigm. 56, 239-249.
Vol. 5 No. 3 (Mar 2012)

ISSN: 0974- 6846

29. Ofomaja AE and Bioresour YS (2008) Effect of temperatures and $\mathrm{pH}$ on methyl violet biosorption by Mansonia wood sawdust. Technol. 99, 5411-5417.

30.Pignatello JJ, Ferrandino FJ, and Huangm LQ (1993) Elution of aged and freshly added herbicides from a Soil, Environ. Sci. Technol. 27, 1563-1571.

31. Ruthven DM and Loughlin KF (1971) The effect of crystallite shape and size distribution on diffusion measurements in molecular sieves, Chem. Eng. Sci. 2, 577-584.

32.Tseng RL (2006). Mesopore control of high surface area $\mathrm{NaOH}$-activated carbon. J. Colloid, Interface Sci. 303, 494-502.

33. Valix M, Cheung WH and McKay G (2004) Preparation of activated carbon using low temperature carbonisation and physical activation of high ash raw bagasse for acid dye adsorption. Chemosphere, 56, 493-501.

34.Wang $X$ and Chen $Y(2008)$ A new two-phase system for the preparation of nearly monodisperse silver nanoparticles, Mater. Lett. 62, 4366-4368.

35.Won SW, Wu G, Ma H, Liu Q, Yan Y, Cui L and Yu YS (2006) Adsorption performance and mechanism in binding of Reactive Red 4 by coke Waste. J. Hazard. Mater. 138, 370-377.

36.Zhuannian L, Anning Z, Guirong W and Xiaoguang Z (2009) Adsorption Behavior of Methyl Orange onto Modified Ultrafine Coal Powder. Chinese J Chem. Engg. 17, 942-948. 